\title{
Responses of carbon dioxide flux and plant biomass to water table drawdown in a treed peatland in northern Alberta: a climate change perspective
}

\author{
T. M. Munir ${ }^{1}$, B. Xu ${ }^{1, *}$, M. Perkins ${ }^{1}$, and M. Strack ${ }^{1}$ \\ ${ }^{1}$ Department of Geography, University of Calgary, Calgary, AB, Canada \\ * now at: NAIT Boreal Research Institute, Peace River, AB, Canada \\ Correspondence to: T. M. Munir (tmmunir@ucalgary.ca)
}

Received: 13 August 2013 - Published in Biogeosciences Discuss.: 13 September 2013

Revised: 10 December 2013 - Accepted: 3 January 2014 - Published: 11 February 2014

\begin{abstract}
Northern peatland ecosystems represent large carbon (C) stocks that are susceptible to changes such as accelerated mineralization due to water table lowering expected under a climate change scenario. During the growing seasons (1 May to 31 October) of 2011 and 2012 we monitored $\mathrm{CO}_{2}$ fluxes and plant biomass along a microtopographic gradient (hummocks-hollows) in an undisturbed dry continental boreal treed bog (control) and a nearby site that was drained (drained) in 2001. Ten years of drainage in the bog significantly increased coverage of shrubs at hummocks and lichens at hollows. Considering measured hummock coverage and including tree incremental growth, we estimate that the control site was a sink of -92 in 2011 and $-70 \mathrm{~g} \mathrm{C} \mathrm{m}^{-2}$ in 2012, while the drained site was a source of 27 and $23 \mathrm{~g} \mathrm{C} \mathrm{m}^{-2}$ over the same years. We infer that, drainage-induced changes in vegetation growth led to increased biomass to counteract a portion of soil carbon losses. These results suggest that spatial variability (microtopography) and changes in vegetation community in boreal peatlands will affect how these ecosystems respond to lowered water table potentially induced by climate change.
\end{abstract}

\section{Introduction}

Northern peatlands, functioning as carbon (C) sink ecosystems of the boreal forest over millennia, have stored approximately one third of global soil carbon (Tarnocai, 2006; Tarnocai et al., 2009; Turunen et al., 2002). These peatlands dominate the Canadian and Albertan landscape with cover- age of 12 and $16 \%$, respectively and contain almost twice as much $\mathrm{C}$ per unit area $\left(115 \mathrm{~kg} \mathrm{~m}^{-2}\right)$ as tropical forests (Carlson et al., 2010; Vitt et al., 2009). Bogs in Western Canada (e.g. Alberta) are often covered by trees in contrast to open bogs in Eastern Canada (Turetsky et al., 2002). In Canada, the large peatland coverage $\left(1.136\right.$ million $\left.\mathrm{km}^{2}\right)$ combined with high carbon density results in a store of approximately $147 \mathrm{Gt}$ of soil organic C (Tarnocai, 2006). The large $\mathrm{C}$ pools formed as a result of net uptake of carbon dioxide $\left(\mathrm{CO}_{2}\right)$ from the atmosphere over millennia, if destabilized through a change in climate (e.g. atmospheric warming and subsequent drought), would lead to accelerated emission of greenhouse gases (GHGs) to the atmosphere (Gruber et al., 2004; IPCC, 2007; Limpens et al., 2008).

The formation and stability of peatland $\mathrm{C}$ stock is sensitive to changes in climatic conditions (e.g. atmospheric temperature and precipitation) (Vitt et al., 2009). Ongoing climate change is predicted to be most severe at northern latitudes where most of the peatlands are situated (Tarnocai, 2006; IPCC, 2007). The Canadian Global Climate Model (CGCM1, 2000) predicts a $3-4{ }^{\circ} \mathrm{C}$ increase in mean annual air temperature by 2020 , with the greatest potential temperature increase $\left(>20^{\circ} \mathrm{C}\right)$ occurring in winter months under extreme climate warming scenarios (Hengeveld, 2000). The increase of air temperature, combined with altered precipitation patterns, could lead to overall decrease in soil moisture across the high latitude region (IPCC, 2007). Drought/warming-induced water table drawdown could have a significant impact on the sustainability and ecosystem functions of boreal peatlands (Tarnocai, 2006; Adkinson et al., 
2011; Blodau and Siems, 2012; Chivers et al., 2009; Ise et al., 2008; Riutta, 2008, 2009; Roulet, 2000; Waddington and Price, 2000; Limpens et al., 2008). The increased atmospheric temperature and lowered water table can cause enhanced rates of organic matter decomposition and $\mathrm{CO}_{2}$ emission, consequently resulting in the gradual depletion of peat C pool (Turetsky and Louis, 2006).

Carbon fluxes in peatlands occur in the forms of the uptake of $\mathrm{C}$ from the atmosphere via gross primary photosynthesis (GPP) and the release of $\mathrm{C}$ to the atmosphere by respiration $(R)$ of plants (autotrophic) and microorganisms (heterotrophic). The sum of GPP and $R$ is defined as the net ecosystem exchange (NEE) of $\mathrm{CO}_{2}$. Net uptake of $\mathrm{CO}_{2}$ causes the accumulation of carbon in the form of plant biomass and soil organic matter. The GPP, $R$ and NEE of the forest floor are denoted by $\mathrm{GPP}_{\mathrm{ff}}, R_{\mathrm{ff}}$ and $\mathrm{NE}_{\mathrm{ff}}$, respectively.

Photosynthesis and autotrophic respiration may vary independently with changing temperature (Ryan, 1995; Ow et al., 2008). Warm and dry conditions in peatlands can either stimulate $\mathrm{CO}_{2}$ uptake by enhanced GPP (e.g. Moore and Dalva, 1993; Updegraff et al., 2001; Syed et al., 2006; Ise et al., 2008; Cai et al., 2010) or reduce C uptake by limiting moisture (Alm et al., 1999; Roulet et al., 2007; Ise et al., 2008). Lowered water table in a treed bog increased tree productivity and fine root biomass significantly in a Canadian (Lieffers and Rothwell, 1987) and a Finnish peatland (Heikurainen and Pakarinen, 1982). Cool temperatures and near-surface water table conditions which typically occur in northern peatland ecosystems suppress respiration (Gorham, 1991; Hanson et al., 2000; Davidson and Janssens, 2006; Chapman and Thurlow, 1998). Predicted warming and subsequent lowered water table will result in enhanced $\mathrm{CO}_{2}$ emissions from northern peatland soils (Moore, 2002; Roulet et al., 1992) where fine tree root biomass may contribute to soil total respiration (Lieffers and Rothwell, 1987). However, while the variation in respiration may not always be linked to fluctuation in water table, it is related to changes in moisture. Thus water table is an important control on respiration in peatlands in which soil peat moisture is sensitive to lowering of water table (Parmentier et al., 2009). Therefore, depending on the balance of GPP and R changes as a consequence of warming and/or drought, there may be a net increase or decrease in thickness of peat (Moore et al., 2006).

Autotrophic respiration by tree/shrub roots may contribute a significant amount to forest floor respiration $\left(R_{\mathrm{ff}}\right)$ when lowered water table stimulates root growth and promotes overall shrub/tree growth in dried peatlands (Lohila et al., 2011). Separating tree root respiration $\left(R_{\mathrm{r}}\right)$ from $R_{\mathrm{ff}}$ is critical in order to attribute the $\mathrm{C}$ losses to various sources of soil respiration and to better understand $\mathrm{C}$ source/sink dynamics (Hanson et al., 2000; Valentini et al., 2000; Janssens et al., 2001) of boreal treed peatlands in the face of global climate change. Isolating $R_{\mathrm{r}}$ from $R_{\mathrm{ff}}$ can make possible the comparison of $\mathrm{CO}_{2}$ fluxes and plant biomass of a treed bog with those of an open bog, provided all controlling variables are similar. The contribution of $R_{\mathrm{r}}$ to $R_{\mathrm{ff}}$ has been quantified using closed chamber technique in various forest ecosystems. Hermle et al. (2010) separated black spruce root respiration from soil total respiration by measuring the difference between control and trenched plots. They found that the $R_{\mathrm{r}}$ was $24 \%$ of the soil total respiration. The contribution of $R_{\mathrm{r}}$ to soil total respiration was higher $(37 \%)$ in a subtropical forest (Wang et al., 2008) in a similar trenching experiment. An even higher contribution of rhizomicrobial respiration was quantified by Hanson et al. (2000) for forest vegetation in Florida.

As peatlands become drier under warming climate, it has been suggested that vegetation communities could shift towards a shrub/tree dominated system (Weltzin et al., 2000; Camill, 1999; Lohila et al., 2011), which in turn could alter the above (Lohila et al., 2011) and belowground C dynamics (Blodau and Siems, 2012). Swedish peatlands drained for forestry have been reported to respire at very high rates of 513-6516 $\mathrm{g} \mathrm{CO}_{2} \mathrm{~m}^{-2} \mathrm{yr}^{-1}$ (von Arnold et al., 2005). A net loss of soil carbon in Finnish peatlands drained for forestry has also been reported with mean value of $150 \mathrm{~g} \mathrm{C} \mathrm{m}^{-2} \mathrm{yr}^{-1}$ (Simola et al., 2012).

The shift in vegetation coverage and $\mathrm{C}$ dynamics vary with microtopographic features (e.g. hummocks $(H)$ and hollows $(W)$ ) in peatlands (e.g. Strack et al., 2006, Waddington and Roulet, 2000) . Also, the relationships between peatland $\mathrm{CO}_{2}$ fluxes and water table may vary spatially between different microtopographic features in peatlands (Charman and Chichester, 2002; Joosten and Clarke, 2002). For example Strack et al. (2006) reported reduced GPP at hummocks and enhanced GPP at hollows and lawns in a water table drawdown experiment in an open, poor fen peatland. Bubier et al. (2003) reported a significant increase in total respiration at bog hollows during a dry summer and no change at hummocks.

Drought response experiments have been conducted in Eastern Canada (for example Waddington and Price, 2000; Strack et al., 2006) where generally most of the peatlands are characterized by their open nature (minimal tree cover) and receive high precipitation that leads to high surface humidity. Climatic and environmental (temperature, precipitation and water table position) response experiments have been conducted in Western Canada (Adkinson et al., 2011; Syed et al., 2006) where in contrast to Eastern Canada, most of the peatlands are generally drier and warmer and are characterized by their tree cover (Vitt et al., 1998; Price, 2010). However, these were short-term responses to drought studies and differences in microtopographic response were not considered. Western Canadian continental treed bogs are expected to respond to predicted climate change differently for $\mathrm{CO}_{2}$ fluxes and plant biomass than those of Eastern Canadian open peatlands, with the potential for vegetation succession when water tables are persistently lowered. Moreover, we are unaware of any drought response $\mathrm{CO}_{2}$ flux and biomass 
change experiments in treed peatland that have measured contribution of $R_{\mathrm{r}}$ to $R_{\mathrm{ff}}$ using the closed chamber technique.

Therefore, our research aimed: (1) to compare $\mathrm{CO}_{2}$ fluxes along a microtopographic gradient (hummock vs. hollow) between natural (control) and drained sites at a continental ombrotrophic bog, (2) to quantify changes in tree biomass and ground-layer biomass along microtopographic gradient in response to drainage, and (3) to determine the contribution of tree root respiration to forest floor respiration as affected by drainage.

\section{Methods}

\subsection{Study sites}

Two sections of a dry continental ombrotrophic bog were selected: one undisturbed section (CONTROL) $\left(+55^{\circ} 21^{\prime} 14.19^{\prime \prime} \mathrm{N} ;-112^{\circ} 31^{\prime} 3.69^{\prime \prime} \mathrm{W}\right)$ and one section that was drained in 2001 (DRAINED) $\left(+55^{\circ} 16^{\prime} 44.28^{\prime \prime} \mathrm{N}\right.$, $\left.-112^{\circ} 28^{\prime} 8.22^{\prime \prime} \mathrm{W}\right)$. The drained site was not specifically drained for forestry but inadvertently drained during horticultural peat extraction operations on nearby sites. The drained site is located near the corner of two main ditches that have effectively drained a large quadrant of the peatland. All plots were within $50 \mathrm{~m}$ of the ditches. The two sections were $9 \mathrm{~km}$ apart and located in north-central Alberta, approximately $85 \mathrm{~km}$ northeast of Athabasca, Alberta, Canada. Both sites are underlain by sandy clay substrate and have peat depth exceeding $4 \mathrm{~m}$. Climate in this region is sub-humid continental with mean annual and growing season (May-October) temperatures at $2.1^{\circ} \mathrm{C}$ and $11.7^{\circ} \mathrm{C}$ (Environment Canada, 2013). Mean annual precipitation at Athabasca is $504 \mathrm{~mm}$, with 382 $\mathrm{mm}$ falling as rain. The research was conducted over two growing seasons (2011-2012). Mean growing season rainfall and air temperatures measured on site were 402.7 and $281.6 \mathrm{~mm}$ and $13.06^{\circ} \mathrm{C}$ and $13.08^{\circ} \mathrm{C}$ for 2011 and 2012 , respectively.

The Wandering River, Alberta bog comes under the class of treed low shrub bogs, with typical mosaic of hummock $(H)$ and hollow $(W)$ microforms (Riley, 2003). The hummocks and hollows at the control site were dominated by Sphagnum mosses with sparse shrubs. The drained site had higher coverage of shrubs on the hummocks and higher lichen coverage in the hollows. Common mosses included Sphagnum fuscum, Sphagnum magellanicum, Sphagnum capillifolium and Pleurozium schreberi while common shrubs included Labrador Tea (Rhododendron groenlandicum), Lingonberry (Vaccinum vitis-idaea), small bog cranberry (Oxycoccos microcarpus) and cloudberry (Rubus chamaemorus). The most common tree in the bog was black spruce (Picea mariana) that constituted $>99 \%$ of the tree stand with 25766 stems ha $^{-1}$ consisted of $37 \%$ taller trees (>137 cm height) up to $769 \mathrm{~cm}$. The black spruce stand had an average canopy height of $168 \mathrm{~cm}$, projection coverage of
$42 \%$ and basal area of $73.5 \mathrm{~m}^{2} \mathrm{ha}^{-1}$. This description applies to the whole bog having control and drained sites.

\section{$2.2 \mathrm{CO}_{2}$ exchange}

At each site, three hummocks and three hollows were chosen as the study plots before the growing season (May-October) of 2011 . A $60 \mathrm{~cm} \times 60 \mathrm{~cm}$ steel collar having grooves at the top was inserted about $6 \mathrm{~cm}$ into the peat at each plot to keep disturbance to roots minimal. The $\mathrm{CO}_{2}$ fluxes were measured weekly during the growing seasons using a closed chamber having dimensions of $60 \mathrm{~cm} \times 60 \mathrm{~cm} \times 30 \mathrm{~cm}(L \times$ $D \times H)$, made of clear acrylic and corrected for transmittance $(88 \%)$. Two small battery-operated fans were installed inside the chamber to circulate the air and achieve equilibrium $\mathrm{CO}_{2}$ concentration between measurements. The instantaneous $\mathrm{CO}_{2}$ concentration in the chamber was monitored with a portable infrared gas analyser (PP systems, USA, EGM-4). Photosynthetically active radiation (PAR) was measured with a quantum sensor (PP systems, USA) placed at the top of the chamber. The temperature inside the chamber was measured with a thermocouple thermometer (VWR Int., USA). All measurements were made at $15 \mathrm{~s}$ intervals for up to $1.75 \mathrm{~min}$. At the time of flux measurements, soil temperatures at the depths of 2, 5, 10, 15, and $20 \mathrm{~cm}$ were measured with a thermocouple thermometer at all plots. Water table relative to moss surface was measured at each $\mathrm{CO}_{2}$ flux measurement occasion from a permanently installed well associated with each plot. We used negative values for indicating belowground water table.

At each plot, a total of $184 \mathrm{CO}_{2}$ flux measurements were made during the daytime of growing seasons (May-October) of 2011 and 2012. During the two growing seasons we organized 20 flux measurement campaigns. Each campaign lasted for about eight days during which fluxes were measured on two to three occasions at each plot. At each flux measurement occasion we took a total of five measurements (four measurements for $\mathrm{NE}_{f f}$ (net exchange of $\mathrm{CO}_{2}$ at the forest floor) under a range of PAR levels created using shades, and a last run for $R_{\mathrm{ff}}$ ) each of $1.75 \mathrm{~min}$ : 2-3 full sun, single shade, double shade and finally opaque tarp (for $R_{\mathrm{ff}}$ ). The chamber was flushed (vented) for enough time between the measurements to bring the headspace concentration in equilibrium with ambient air concentration. Therefore we measured respiration as the final measurement (after about $18 \mathrm{~min}$ ) at each plot by using the clear chamber covered with an opaque shroud. In this way any buildup of $\mathrm{CO}_{2}$ in the soil would have already been flushed. Thus problems in determining respiration rates caused by flushing $\mathrm{CO}_{2}$ built up in the soil during night time chamber measurements (Lai et al., 2012; Koskinen et al., 2013) were not an issue for our measurements.

As noted above, $\mathrm{CO}_{2}$ flux measurements in the dark (when the chamber was covered with an opaque shroud) represented $R_{\mathrm{ff}}$. We recognize that this $R_{\mathrm{ff}}$ represents only forest floor respiration including understory aboveground biomass 
Table 1. Estimated parameter values $( \pm \mathrm{SE})$, standard error of the estimate (SEE) and goodness of fit $\left(r^{2}\right)$ for the gross primary production of forest floor $\left(\mathrm{GPP}_{\mathrm{ff}}\right)$ Model (Eq. 1)*.

\begin{tabular}{|c|c|c|c|c|c|c|c|c|c|}
\hline \multirow[b]{2}{*}{ Year } & \multirow[b]{2}{*}{ Site/Microform } & \multicolumn{2}{|c|}{$\mathrm{GPP}_{\mathrm{ff}}$ vs. PAR } & \multicolumn{2}{|c|}{$\mathrm{GPP}_{\mathrm{ff}}$ vs. WT } & \multicolumn{2}{|c|}{$\mathrm{GPP}_{\mathrm{ff}}$ vs. $T$} & \multirow{2}{*}{$\frac{\mathrm{SEE}}{\left(\mathrm{g} \mathrm{CO}_{2}\right.} \frac{\left.\mathrm{m}^{-2} \mathrm{~d}^{-1}\right)}{}$} & \multirow[t]{2}{*}{$r^{2}$} \\
\hline & & $\begin{array}{c}P_{\max } \\
\left(\mathrm{g} \mathrm{CO}_{2}\right. \\
\left.\mathrm{m}^{-2} \mathrm{~d}^{-1}\right)\end{array}$ & $\begin{array}{c}k \\
(\mu \mathrm{mol} \\
\left.\mathrm{m}^{-2} \mathrm{~s}^{-1}\right)\end{array}$ & $\begin{array}{c}\mathrm{WT}_{\mathrm{opt}} \\
(\mathrm{cm})\end{array}$ & $\begin{array}{c}\mathrm{WT}_{\text {tol }} \\
(\mathrm{cm})\end{array}$ & $\begin{array}{l}T_{\mathrm{Opt}} \\
\left({ }^{\circ} \mathrm{C}\right)\end{array}$ & $\begin{array}{l}T_{\text {tol }} \\
\left({ }^{\circ} \mathrm{C}\right)\end{array}$ & & \\
\hline \multirow[t]{4}{*}{2011} & Control Hummocks & $-22.2 \pm 4.6$ & $900 \pm 422$ & $-56.0 \pm 13.0$ & $30.0 \pm 15.8$ & $16.1 \pm 3.7$ & $10.0 \pm 5.4$ & 2.30 & 0.83 \\
\hline & Control Hollows & $-19.4 \pm 7.1$ & $950 \pm 601$ & $-28.3 \pm 9.7$ & $22.9 \pm 21.3$ & $14.1 \pm 7.5$ & $10.0 \pm 12.5$ & 2.05 & 0.63 \\
\hline & Drained Hummocks & $-35.9 \pm 8.8$ & $950 \pm 440$ & $-118.1 \pm 8.3$ & $30.0 \pm 11.1$ & $12.3 \pm 1.5$ & $10.0 \pm 3.1$ & 1.14 & 0.82 \\
\hline & Drained Hollows & $-29.2 \pm 16.8$ & $850 \pm 639$ & $-70.5 \pm 31.6$ & $30.0 \pm 17.3$ & $10.6 \pm 2.7$ & $10.0 \pm 10.2$ & 0.57 & 0.68 \\
\hline \multirow[t]{4}{*}{2012} & Control Hummocks & $-24.8 \pm 4.7$ & $900 \pm 286$ & $-34.9 \pm 11.3$ & $30.0 \pm 14.0$ & $15.2 \pm 2.0$ & $10.0 \pm 3.8$ & 1.84 & 0.86 \\
\hline & Control Hollows & $-21.8 \pm 3.9$ & $950 \pm 299$ & $-42.3 \pm 13.8$ & $30.0 \pm 20.1$ & $14.6 \pm 1.3$ & $9.9 \pm 2.1$ & 1.09 & 0.85 \\
\hline & Drained Hummocks & $-50.0 \pm 14.3$ & $950 \pm 416$ & $-104.8 \pm 2.8$ & $30.0 \pm 2.9$ & $10.1 \pm 2.0$ & $10.0 \pm 2.0$ & 0.96 & 0.82 \\
\hline & Drained Hollows & $-31.3 \pm 10.1$ & $850 \pm 246$ & $-99.5 \pm 11.1$ & $23.2 \pm 6.7$ & $10.0 \pm 5.5$ & $9.9 \pm 4.6$ & 1.55 & 0.83 \\
\hline
\end{tabular}

* The models were developed for each microform type $(n=3)$ at the control and drained sites separately for growing seasons of 2011 and 2012 . PAR, WT and $T$ represent photosynthetically active radiation, water table (negative values show belowground water level) and $5 \mathrm{~cm}$ soil temperature, respectively. $P_{\max }$ denotes potential maximum rate of $\mathrm{GPP} \mathrm{ff}_{\mathrm{ff}}$ and $k$ is level of PAR at which half of GPPf $\mathrm{ff}_{\mathrm{ff}}$ occurs. WT $\mathrm{T}_{\mathrm{opt}}$ and $T_{\mathrm{opt}}$ are Gaussian response parameters for optimum GPP $\mathrm{ff}_{\mathrm{fhile}} \mathrm{WT}_{\mathrm{tol}}$ and $T_{\mathrm{tol}}$ are Gaussian response parameters describing the width of the curve. All modeled parameters are significant at $p=0.05$ level.

respiration, heterotrophic soil respiration and tree root respiration, and ignores respiration of the overstory aboveground tree biomass. $\mathrm{GPP}_{\mathrm{ff}}$ was determined as the difference between $\mathrm{NE}_{\mathrm{ff}}$ and $R_{\mathrm{ff}}$. We used the convention that negative values indicate an uptake of $\mathrm{CO}_{2}$ by the ecosystem.

Net exchange of $\mathrm{CO}_{2}$ at the forest floor $\left(\mathrm{NE}_{\mathrm{ff}}\right)$ was calculated using exponential change (Kutzbach et al., 2007) instead of linear change in $\mathrm{CO}_{2}$ concentration in the chamber headspace with time, as a function of volume, air temperature and pressure inside the chamber, according to ideal gas law. The exponential regression was used because covering soil and/or vegetation essentially manipulates the spontaneous $\mathrm{CO}_{2}$ fluxes by altering the concentration gradients between the soil, the vegetation and the air inside the chamber. Due to the constantly changing controls on $\mathrm{CO}_{2}$ flux within the chamber, no linear decrease or increase of $\mathrm{CO}_{2}$ concentration inside the chamber can be expected. Kutzbach et al. (2007) found that the linear $\mathrm{CO}_{2}$ fluxes compared with exponential fluxes were up to $40 \%$ lower, over $\mathrm{CO}_{2}$ chamber closure time of only two minutes.

Maximum rates of $\mathrm{GPP}_{\mathrm{ff}}\left(\mathrm{GPP}_{\max }\right)$ and $\mathrm{NE}_{\mathrm{ff}}\left(\mathrm{NE}_{\max }\right)$ represent $\mathrm{GPP}_{\mathrm{ff}}$ and $\mathrm{NE}_{\mathrm{ff}}$ when the photon flux density of photosynthetically active radiation is greater than $1000 \mu \mathrm{mol} \mathrm{m} \mathrm{m}^{-2} \mathrm{~s}^{-1}$. As modeled values of the maximum rate of photosynthesis are likely never achieved in reality, these values represent a more realistic estimate of $\mathrm{CO}_{2}$ exchange when light is not limiting as discussed in Bubier et al. (2003). We use these to statistically compare between plots to better understand processes (changes in plant cover, species type, water table, etc.) that affect $\mathrm{CO}_{2}$ exchange. Data reported are averages for the study seasons (May-October) for all occasions when PAR $>1000 \mu \mathrm{mol} \mathrm{m}{ }^{-2} \mathrm{~s}^{-1}$.

\subsubsection{Seasonal $\mathrm{CO}_{2}$ exchange model}

The growing season (1 May to 31 October) GPP $_{\mathrm{ff}}$ was estimated using an empirical model following Riutta et al. (2007) parameterized separately for each microform type $\times$ water table treatment. The parametrization was done separately for each of the growing seasons of 2011 and 2012. The seasonal GPP $\mathrm{ff}_{\mathrm{ff}}$ was estimated by

$$
\begin{array}{r}
\mathrm{GPP}_{\mathrm{ff}}=\frac{\mathrm{PAR} \times P_{\mathrm{max}}}{\mathrm{PAR}+k} \times e^{\left[-0.5 \times\left(\frac{\mathrm{WT}-\mathrm{WT}_{\mathrm{opt}}}{\mathrm{WT}_{\mathrm{tol}}}\right)^{2}\right]} \\
\times e^{\left[-0.5 \times\left(\frac{\mathrm{T}-T_{\mathrm{opt}}}{T_{\mathrm{tol}}}\right)^{2}\right]},
\end{array}
$$

where $P_{\max }$ denotes the potential maximum rate of $\mathrm{GPP}_{\mathrm{ff}}(\mathrm{g}$ $\mathrm{CO}_{2} \mathrm{~m}^{-2} \mathrm{~d}^{-1}$ ) if water table and temperature are not limiting and the parameter $k$ denotes the level of PAR at which half of the $P_{\max }$ occurs. WT is the water table position $(\mathrm{cm}), \mathrm{WT}_{\mathrm{opt}}$ and $\mathrm{WT}_{\text {tol }}$ are parameters in a Gaussian response of $\mathrm{GPP}_{\mathrm{ff}}$ to water table when $\mathrm{GPP}_{\mathrm{ff}}$ is optimized and width of the curve respectively, $T$ is the soil temperature $\left({ }^{\circ} \mathrm{C}\right)$ at $5 \mathrm{~cm}$ below moss surface and $T_{\mathrm{opt}}$ and $T_{\mathrm{tol}}$ are parameters in a Gaussian response of $\mathrm{GPP}_{\mathrm{ff}}$ to the soil temperature when $\mathrm{GPP}_{\mathrm{ff}}$ is optimized and width of the curve.

Model parameters for seasonal $\mathrm{GPP}_{\mathrm{ff}}$, standard errors $( \pm)$, $r^{2}$ values, and standard errors of the estimates at control and drained microforms are presented in Table 1. Two-thirds of the data were randomly selected and used for model construction, whereas one-third of the data were used for independent testing of the models following Tuittila et al. (2004).

After examining the data it appeared that the relationship of $R_{\mathrm{ff}}$ with soil temperature at $5 \mathrm{~cm}$ depth was not exponential. Therefore the growing season $R_{\mathrm{ff}}$ was estimated using multiple linear regressions with soil temperature at $5 \mathrm{~cm}$ 
Table 2. Estimated regression coefficient values $( \pm \mathrm{SE})$, standard error of the estimate (SEE) and goodness of fit $\left(r^{2}\right)$ for the forest floor respiration $\left(R_{\mathrm{ff}}\right)$ model (Eq. 2$)^{*}$.

\begin{tabular}{llccccc}
\hline Year & Site/Microform & $a$ & $b$ & $c$ & SEE $\left(\mathrm{g} \mathrm{CO}_{2} \mathrm{~m}^{-2} \mathrm{~d}^{-1}\right)$ & $r^{2}$ \\
\hline \multirow{2}{*}{2011} & Control Hummocks & $1.30 \pm 0.29$ & $-0.21 \pm 0.12$ & $-18.25 \pm 6.80$ & 0.80 & 0.81 \\
& Control Hollows & $1.70 \pm 0.32$ & $-0.61 \pm 0.20$ & $-32.33 \pm 10.74$ & 0.68 & 0.79 \\
& Drained Hummocks & $0.31 \pm 0.27$ & $-0.02 \pm 0.03$ & $2.62 \pm 7.26$ & 0.38 & 0.49 \\
& Drained Hollows & $0.55 \pm 0.13$ & $-0.02 \pm 0.03$ & $2.26 \pm 3.63$ & 0.19 & 0.85 \\
\hline \multirow{2}{*}{2012} & Control Hummocks & $0.39 \pm 0.15$ & $-0.25 \pm 0.09$ & $-10.71 \pm 5.31$ & 0.61 & 0.53 \\
& Control Hollows & $0.93 \pm 0.08$ & $-0.25 \pm 0.05$ & $-12.77 \pm 1.77$ & 0.36 & 0.81 \\
& Drained Hummocks & $0.65 \pm 0.06$ & $-0.03 \pm 0.05$ & $-3.40 \pm 8.14$ & 0.32 & 0.91 \\
& Drained Hollows & $1.07 \pm 0.09$ & $-0.15 \pm 0.04$ & $-17.31 \pm 5.55$ & 0.86 & 0.80 \\
\hline
\end{tabular}

* The models were developed for each microform type $(n=3)$ at the control and drained sites separately for growing seasons of 2011 and $2012 ; a, b$ and $c$ are regression coefficients. Negative values of $b$ represent greater respiration with deeper water table values (belowground WT having negative values). All modeled parameters are significant at $p=0.05$ level.

depth and water table position by

$R_{\mathrm{ff}}=a \times T+b \times \mathrm{WT}+c$,

where $a, b$ and $c$ are regression coefficients (Table 2).

Seasonal GPP ff $_{\text {and }} R_{\mathrm{ff}}$ were estimated based on Eqs. (1) and (2) for each twenty minute period between 1 May and 31 October, averaged daily and summed for a growing season total based on measurements made on sites for PAR (LI-190, LI-COR, Nevada, USA), WT (Levelogger Junior, Solinst, USA) and temperature (Onset HOBOware Pro, MA, USA). Growing season ground-layer $\mathrm{NE}_{\mathrm{ff}}$ was determined by adding seasonal $\mathrm{GPP}_{\mathrm{ff}}$ to seasonal $R_{\mathrm{ff}}$ estimates. The control site was instrumented with one additional soil temperature sensor (T 109, Campbell Scientific Inc., Utah, $\mathrm{USA}$; depth $=5 \mathrm{~cm}$ ) and one tipping bucket rain gauge (TE 525, Campbell Scientific Inc., Utah, USA; height $=150 \mathrm{~cm}$ ) both wired to a data logger (CR 1000, Campbell Scientific Inc., Utah, USA) programmed to measure every minute and record the average at $20 \mathrm{~min}$ intervals.

\subsubsection{Model validation}

Of all the data measured in the field, we separated one third randomly and did not use it for model construction. The remaining two-thirds of the data were used for model construction. The unused data were later correlated with modeled data for validation of the $\mathrm{GPP}_{\mathrm{ff}}$ and $R_{\mathrm{ff}}$ models. Validation of the model showed excellent agreement between predicted and measured values (Fig. 1a and b).

\subsection{Tree root respiration}

To exclude the contribution of $R_{\mathrm{r}}$ to $R_{\mathrm{ff}}$, a trenching method (Wang et al., 2008) was used. In May 2012, a total of 32 plots (eight hummocks and eight hollows at each site, in addition to the already described $\mathrm{CO}_{2}$ flux plots) were chosen randomly from the available microtopography. At each site four hummock and four hollow plots of area $60 \mathrm{~cm} \times 60 \mathrm{~cm}$ were cut around up to approximately $30 \mathrm{~cm}$ depth in three intervals $(0-10 \mathrm{~cm}, 10-20 \mathrm{~cm}, 20-30 \mathrm{~cm})$. It was assumed that cutting the peat would cut down most of the live root ingrowth. To make the cut loose enough to insert polyethylene sheet, we had to use a saw several times at each of the three depth intervals. Then the polyethylene sheet was inserted deep to $30 \mathrm{~cm}$ to prevent root ingrowth and the cuts were infilled with soil in the reverse order of removal (i.e., first we filled back the soil from $20-30 \mathrm{~cm}$ depth followed by $10-20 \mathrm{~cm}$ and lastly $0-10 \mathrm{~cm})$. Although this procedure did not ensure that the backfilled soil occupied its original place, our intention was to keep disturbance minimal. The remaining four hummocks and four hollows were left intact to quantify the difference in $\mathrm{CO}_{2}$ emission between cut (having minimal tree roots) and intact (with all tree roots) plots. During July to September 2012, all plots were clipped every two weeks to ensure that soil surface was free of live mosses, shrubs and herbs following Hanson et al. (2000), Riutta et al. (2007) and Hermle et al. (2010). The trenched and intact plots were clipped so that we could isolate soil respiration (measured at trenched plots) from $R_{\mathrm{r}}+$ soil respiration (measured at intact plots). Had the plots not been clipped, we would have measured $R_{\mathrm{r}}+$ soil respiration + autotrophic respiration of surface vegetation at intact plots and soil respiration + autotrophic respiration of surface vegetation at trenched plots. This way we could not have $R_{\mathrm{r}}$ separated from soil respiration. The surface vegetation was clipped with Fiskars power lever shears (Model \# 100017192) that clips horizontally to keep disturbance minimal.

The $\mathrm{CO}_{2}$ emissions from all plots were measured using the same instruments and chamber used for the measurement of $\mathrm{NE}_{\mathrm{ff}}$ and $R_{\mathrm{ff}}$ and hence $\mathrm{GPP}_{\mathrm{ff}}$. We had a methodological challenge that while the cutting separates $R_{\mathrm{r}}$ from $R_{\mathrm{ff}}$, it also adds fresh litter to the soil that can add to the existing heterotrophic soil respiration.

Trenching or cutting experiments have been performed to separate root autotrophic respiration from $R_{\mathrm{ff}}$ (e.g. Hanson 

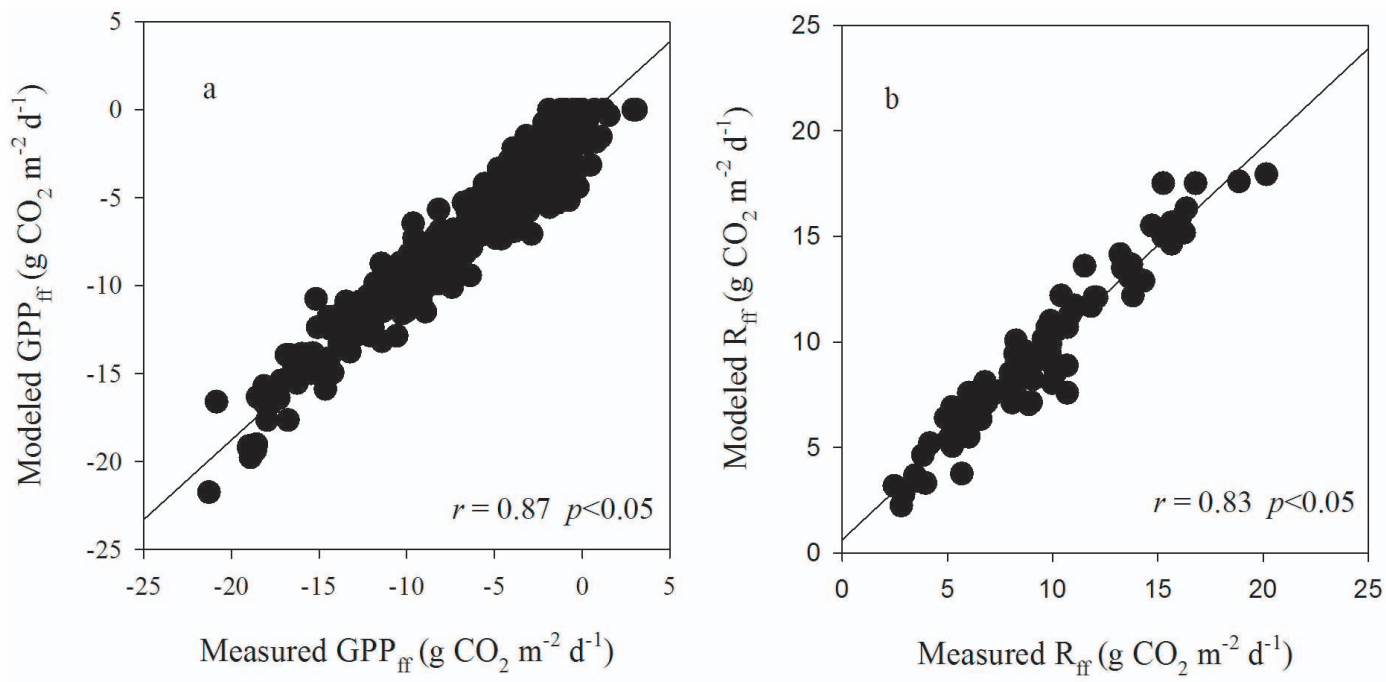

Fig. 1. Goodness of fit $\left(r^{2}\right)$ between (a) modeled and measured $\mathrm{GPP}_{\mathrm{ff}}$ and (b) modeled and measured $R_{\mathrm{ff}}$. The measured data used in these figures were chosen randomly and were not used for construction of models. Both 2011 and 2012 data from control and drained sites are presented. Lines represent the $1: 1$ fit.

et al., 2000; Hermle et al., 2010; Wang et al., 2008; Díaz Pinés et al., 2010; Kuzyakov, 2006; Brant et al., 2006). In all cases the assumption has been made that the trenched roots die off within a short time and that afterwards the measured $R_{\mathrm{ff}}$ can solely be attributed to heterotrophic soil respiration. Trenching immediately disrupts the supply of recent photosynthates to the roots and mycorrhiza. The mycorrhizal fungi and associated bacteria will suffer from the lack of labile C. Bowden et al. (1993), Boone et al. (1998) and Rey et al. (2002) in trenching or cutting experiments showed that $\mathrm{C}$ content of decomposing fine roots in trenched plots contribute little to $R_{\mathrm{r}}$ and become stable in the four months after trenching. Therefore, no correction for extra $\mathrm{CO}_{2}$ from decaying fine roots is necessary. However, the root exclusion experiment may not be useful if extended through a complete annual cycle, as over such a long period there is the possibility of reinvasion of roots into the previously root-free trenched plot (Edwards and Norby, 1999). While it is clear that findings from such trenching measurements should be interpreted carefully, the primary focus of this paper is to quantify $R_{\mathrm{ff}}$ while investigating $R_{\mathrm{r}}$ to better understand and separate the contribution of various processes to shifts in $R_{\mathrm{ff}}$ following drainage.

\subsection{Biomass and tree productivity}

Forest floor biomass was measured by clipping $25 \mathrm{~cm} \times 25 \mathrm{~cm}$ quadrats at nine hummocks and nine hollows, at each of control and drained sites, in mid-July 2011. The biomass was clipped at the base of the capitulum at $1.0 \mathrm{~cm}$ below moss surface following Clymo (1970) and Loisel et al. (2012). From triplicate of each microform at each site, soil cores of only $20 \mathrm{~cm}$ depth were collected due to frozen peat beyond this depth at the time of sample collection. The soil cores were sectioned into two depths $(0-10$ and $10-20 \mathrm{~cm})$ and roots were sorted into coarse $(>2 \mathrm{~mm})$ and fine $(<2 \mathrm{~mm})$ fractions. For tree biomass, we selected three $10 \mathrm{~m} \times 10 \mathrm{~m}$ quadrats in areas directly surrounding the flux plots at each site. The total study areas were not large and these plots covered most of the trees in the study areas. Trees were divided into tall $(>137 \mathrm{~cm}$ height) and short ( $<137 \mathrm{~cm}$ height) for biomass estimation. All trees were measured for their height, diameter at breast height (DBH, when tall enough) and basal diameter (DB). Tall tree biomass was calculated by using an allometric equation (dry biomass $=0.153$ (tree DBH) ${ }^{2.248}$ ) from Grigal and Kernik (1984). Trees $<137 \mathrm{~cm}$ were not measured for DBH as their total height was below a standard DBH measurement height. A subsample of 20 smaller trees $>125 \mathrm{~cm}$ were harvested parallel to the forest floor and taken back to the lab and oven dried at $80^{\circ} \mathrm{C}$ for 48 hours. The height and dry biomass of each tree was measured and an exponential regression was performed. An allometric equation was generated by regressing height with oven-dried weight as dry biomass $=0.0085$ (tree height $)^{2.2088}\left(R^{2}=0.93, p<0.001\right)$.

For calculating NPP of the tree stand, we adapted methods of Szumigalski and Bayley (1996) and Thormann and Bayley (1997). In addition to fens, they also estimated NPP of an Alberta ombrotrophic treed bog of hummock-hollow microtopography by adding aboveground incremental biomass to stand litter production (17\% of incremental biomass $\mathrm{m}^{-2} \mathrm{yr}^{-1}$ for Picea mariana). We quantified the incremental biomass of tall trees for 2011 and 2012 based on tree ring widths using DendroScan (Varem-Sanders et al., 1996). The incremental biomass of short trees for 2011 and 2012 was calculated by regressing leader length with height following 
Table 3. Ground-layer and tree biomass $\left(\mathrm{g} \mathrm{m}^{-2}\right)$ at control and drained sites.

\begin{tabular}{|c|c|c|c|c|c|c|c|c|c|}
\hline \multirow{2}{*}{$\begin{array}{l}\text { Site/ } \\
\text { Microform }\end{array}$} & \multicolumn{4}{|c|}{ ABOVEGROUND } & \multicolumn{3}{|c|}{ BELOWGROUND } & \multirow[t]{2}{*}{ TREES } & \multirow[t]{2}{*}{ TOTAL } \\
\hline & Moss & Vascular & Lichen & Total & Fine $(<2 \mathrm{~mm})$ & Coarse $(>2 \mathrm{~mm})$ & Total & & \\
\hline Control Hummocks & $215 \pm 68^{A}$ & $218 \pm 84^{\mathrm{A}}$ & $0 \pm 0^{\mathrm{A}}$ & $433 \pm 147^{\mathrm{A}}$ & $563 \pm 103$ & $138+31$ & $701 \pm 106$ & $2142 \pm 376$ & $3304 \pm 793$ \\
\hline Control Hollows & $182 \pm 93^{\mathrm{A}}$ & $135 \pm 41^{\mathrm{A}}$ & $11 \pm 32^{\mathrm{A}}$ & $328 \pm 72^{\mathrm{A}}$ & $484 \pm 195$ & $386 \pm 425$ & $870 \pm 553$ & & \\
\hline Drained Hummocks & $16 \pm 27^{\mathrm{B}}$ & $737 \pm 60^{\mathrm{B}}$ & $13 \pm 14^{\mathrm{A}}$ & $766 \pm 323^{B}$ & $470 \pm 96$ & $498 \pm 262$ & $967 \pm 275$ & $1964 \pm 381$ & $3676 \pm 1029$ \\
\hline Drained Hollows & $80 \pm 130^{\mathrm{A}}$ & $133 \pm 44^{\mathrm{A}}$ & $358 \pm 354^{\mathrm{B}}$ & $571 \pm 280^{\mathrm{AB}}$ & $491 \pm 60$ & $626 \pm 392$ & $1118 \pm 422$ & & \\
\hline
\end{tabular}

* Values are means \pm SE ( $n=9$ for aboveground ground layer; $n=3$ for belowground; $n=3$ for trees). Means sharing same letters do not differ significantly. Letters should be compared only within one column Total biomass was determined by weighting ground layer by the proportion of hummocks and hollows at each site (control $=56 \%$ hummocks; drained $=52 \%$ hummocks).

Mullin et al. (1992) and Macdonald and Lieffers (1990). Summation of biomass increments of tall and short trees for a year represented incremental biomass of tree stand for aboveground parts of the trees $\left(\mathrm{IC}_{\text {biom_ag }}\right)$ for that year at either site. However, litterfall was not estimated. Therefore we predicted a value of stand litter production based on Szumigalski and Bayley (1996; $17 \%$ of incremental biomass) for Alberta ombrotrophic bogs. We also did not measure incremental biomass of the belowground parts of the tree ( $\mathrm{IC}_{\text {biom_bg }}$ ) due to the difficulty in measuring this component without disturbing our study sites for future monitoring. Therefore, we use an allometric equation (tree root biomass $=0.222^{*}$ tree aboveground biomass) from $\mathrm{Li}$ et al. (2003) for estimating incremental biomass of tree roots.

\section{$2.5 \mathrm{CO}_{2}-\mathrm{C}$ balance calculations}

The $\mathrm{CO}_{2}-\mathrm{C}$ balances of the treed control and drained sites (NEE) were calculated separately for the growing seasons (1 May to 31 October) of 2011 and 2012 as

$\mathrm{NEE}=\mathrm{NE}_{\mathrm{ff}}+\mathrm{IC}_{\text {tree_ag }}+\mathrm{IC}_{\text {tree } \_ \text {bg }}+L_{\text {tree }}-R_{\mathrm{r}}$,

where NEE denotes net ecosystem exchange, $\mathrm{NE}_{\text {ff }}$ represents net exchange of $\mathrm{CO}_{2}$-C of the forest floor, $\mathrm{IC}_{\text {tree_ag }}$ and $\mathrm{IC}_{\text {tree_bg }}$ represent incremental biomass growth of the aboveground and belowground parts of the trees, respectively, $L_{\text {tree }}$ is tree litter production and $R_{\mathrm{r}}$ is tree root respiration.

Seasonal $\mathrm{CO}_{2}$ fluxes at hummocks and hollows were upscaled by multiplying mean estimated growing season $\mathrm{CO}_{2}$ exchange by their respective coverage of 56 and $44 \%$ and 52 and $48 \%$ at the control and drained sites, respectively (Table 4). The incremental growth of the trees and their litter production was added to the forest floor $\mathrm{CO}_{2}$ exchange assuming that biomass had a carbon content of $50 \%$. $R_{\mathrm{r}}$ was excluded to avoid double counting while determining $\mathrm{CO}_{2}$ $\mathrm{C}$ balance of sites as $\mathrm{IC}_{\text {tree bg }}$ already accounts for $R_{\mathrm{r}}$. We estimated a seasonal value of $R_{\mathrm{r}}$ by determining it as a proportion of $R_{\mathrm{ff}}$ based on instantaneous measurements and then estimating it as this proportion of the modelled seasonal $R_{\mathrm{ff}}$.

\subsection{Statistical analysis}

Differences in $\mathrm{GPP}_{\max }, R_{\mathrm{ff}}, \mathrm{NE}_{\max }$, and aboveground biomass between sites and microforms were tested by twoway ANOVA, using Minitab 16.0 (Minitab Inc., PA, USA). Differences in $R_{\mathrm{r}}$ between sites, microforms and cut and intact plots were tested for significance employing a three-way ANOVA using SPSS 20.1. The nonlinear and linear regression models (Eqs. 1, 2 and 3) were used to construct $\mathrm{GPP}_{\mathrm{ff}}$ and $R_{\mathrm{ff}}$ models (SPSS 20.1) and to estimate seasonal $\mathrm{CO}_{2}-\mathrm{C}$ balance.

\section{Results}

\subsection{Site conditions}

Ten years after initial drainage, the water table at the drained site was as much as $80 \mathrm{~cm}$ lower than that at the control site (Fig. 2). The growing seasons of 2011 and 2012 were warmer by 1.36 and $1.38^{\circ} \mathrm{C}$, respectively, and wetter by $41.9 \mathrm{~mm}$ in 2011 and drier by $79.2 \mathrm{~mm}$ in 2012 than $30 \mathrm{yr}$ average at Athabasca. In 2012, the reduction in rainfall by $121 \mathrm{~mm}$ led to a decrease in water table level at control and drained hollows by 4.5 and $4.3 \mathrm{~cm}$ and at control and drained hummocks by 8.0 and $7.2 \mathrm{~cm}$, respectively (Fig. 2).

The drained site was ditched around in 2001 and the data on pre-drawdown hydrology and vegetation were not available. However, given that the control and drained sites were part of the same bog and had similar vegetation layers (canopy layer consisted of Picea mariana and ground layer consisted of similar shrubs and mosses), air temperature, peat depth and underlain substrate are assumed to be similar before start of this study in 2001. As a result of $10 \mathrm{yr}$ drainage, Sphagnum coverage at the drained site was significantly reduced by $97 \%(F(3,32)=33.40, p<0.001)$ compared to the control site, but no significant difference in Sphagnum coverage was observed between microforms at either site (Fig. 3). Sphagnum at drained site was replaced by shrubs at hummocks and lichens at hollows (field observation, data not presented here). The significant reduction in coverage of Sphagnum at the drained site was due to the unfavourable condition of very low water potential in the surface soil. 
Table 4. Growing season $\mathrm{CO}_{2}-\mathrm{C}$ flux estimates $\left( \pm \mathrm{SE}, \mathrm{g} \mathrm{C} \mathrm{m}^{-2}\right)^{\mathrm{a}}$.

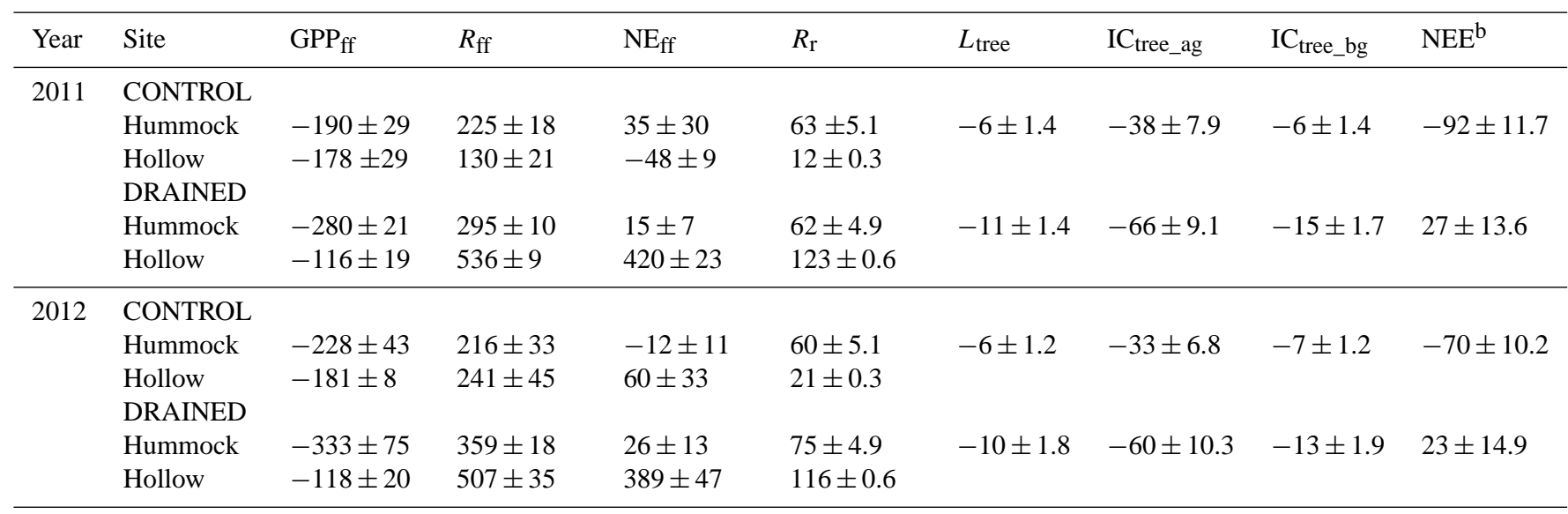

${ }^{\text {a }}$ Negative values represent uptake of carbon by the peatland from the atmosphere. The forest floor respiration $\left(R_{\mathrm{ff}}\right)$ includes tree root respiration $\left(R_{\mathrm{r}}\right)$. ${ }^{\mathrm{b}} \mathrm{NEE}$ is calculated using equation $3\left(\mathrm{NEE}=\mathrm{NE}_{\mathrm{ff}}+\mathrm{IC}_{\text {tree_ag }}+\mathrm{IC}_{\text {tree_bg }}+L_{\mathrm{tree}}-R_{\mathrm{r}}\right)$. Forest floor carbon exchange was determined by weighting $\mathrm{NE}$ ff measured at each microform by the proportion of hummocks and hollows at each site ( $\operatorname{control}=56 \%$ hummocks; drained $=52 \%$ hummocks).

\subsection{Biomass and incremental tree growth}

Vascular plant biomass at the drained hummocks was significantly higher than that at the control hummocks $(F(1$, $32)=17.07, p<0.001)$ and there was a significant interaction between drainage and microform $(F(1,32)=35.74$, $p<0.001)$, while there was no difference between control and drained hollows (Table 3, Fig. 3). Conversely, moss biomass at drained hummocks was significantly lowest of all plots $(F(1,32)=26.28, p<0.001)$. In fact, moss biomass at the drained site was overall much lower than at the control site regardless of microform type, indicating a strong decline of moss cover with drainage. Lichen biomass on the other hand showed an increase following drainage, but it was the drained hollows that had the highest lichen biomass (over 30 times higher than control hollows; $F(1,32)=7.9$, $p=0.008)$ and the interaction between drainage and microform was statistically significant. As a whole, aboveground biomass was highest at drained hummocks $(F(1$, $32)=14.24, p=0.003$ ) while lowest at control hollows. Neither total belowground root biomass nor tree biomass were significantly different between microforms and/or sites. However, total root biomass was higher in the drained site than that in the control (Table 3).

Although tree biomass was higher in the control site by $178 \mathrm{~g} \mathrm{~m}^{-2}$, the annual aboveground tree increment during the study years (2011 and 2012) was significantly higher in the drained site (66 and $60 \mathrm{~g} \mathrm{C} \mathrm{m}^{-2}$ ) than the control (38 and $\left.33 \mathrm{~g} \mathrm{C} \mathrm{m}^{-2}\right)(F(1,3)=3025, p=0.012)$. Using equations presented in $\mathrm{Li}$ et al. (2003) belowground tree increment was estimated as 6 and $7 \mathrm{~g} \mathrm{C} \mathrm{m}^{-2}$ at the control site and 15 and $13 \mathrm{~g} \mathrm{C} \mathrm{m}^{-2}$ at the drained site in 2011 and 2012, respectively (Table 4).

Spatial variability in tree stands is a generic characteristic of natural/peatland ecosystems and we did not have tree stand data prior to the study period. Heterogeneity even between the three quadrats constructed at each site was large; however, the size of the study areas precluded our ability to include more replicates. Therefore, while we cannot be certain that the biomass was identical before the study, they were likely similar and we did see a clear change in tree growth (based on the tree rings) coinciding with the ditching $10 \mathrm{yr}$ ago. Thus we are confident that the changes in incremental growth determined represent a clear response to the changing water table.

\section{$3.3 \mathrm{CO}_{2}$ fluxes}

\subsubsection{Measured $\mathrm{CO}_{2}$ Fluxes}

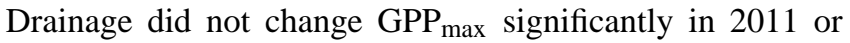
2012 (Fig. 4; two-way ANOVA, 2011: $F=0.06, p=0.813$, 2012: $F=4.13, p=0.08$ ). However, $\mathrm{GPP}_{\max }$ was significantly higher at hummocks than hollows (2011: $F=7.84$, $p=0.027,2012: F=8.99, p=0.017)$. Drainage had a significant interaction with microtopography in 2012 leading to significantly different $\mathrm{GPP}_{\max }$ at drained microforms. Drainage resulted in significantly higher $R_{\mathrm{ff}}$ (2011: $F=$ 6.85, $p=0.037,2012: F=8.52, p=0.019)$, but $R_{\mathrm{ff}}$ remained statistically similar between microforms at both sites in both years. The drained hollows were the largest sources of $\mathrm{CO}_{2}$ emission largely due to the significantly higher contribution of $R_{\mathrm{r}}\left(5.03 \mathrm{~g} \mathrm{CO}_{2} \mathrm{~m}^{-2} \mathrm{~d}^{-1}\right)$ to $R_{\mathrm{ff}}(18.02 \mathrm{~g}$ $\mathrm{CO}_{2} \mathrm{~m}^{-2} \mathrm{~d}^{-1}$ ) than that of the $R_{\mathrm{r}}$ contribution of $1.51 \mathrm{~g}$ $\mathrm{CO}_{2} \mathrm{~m}^{-2} \mathrm{~d}^{-1}$ to $R_{\mathrm{ff}}\left(11.84 \mathrm{~g} \mathrm{CO}_{2} \mathrm{~m}^{-2} \mathrm{~d}^{-1}\right)$ at control hollows (see 2012 in Fig. 4). $\mathrm{NE}_{\max }$ was positive in 2011 but became negative (net sink of $\mathrm{CO}_{2}$ ) in 2012 at control microforms. Subtracting $R_{\mathrm{r}}$ from $\mathrm{NE}_{\max }$ switched the drained hummocks to a moderate sink and the control microforms to 


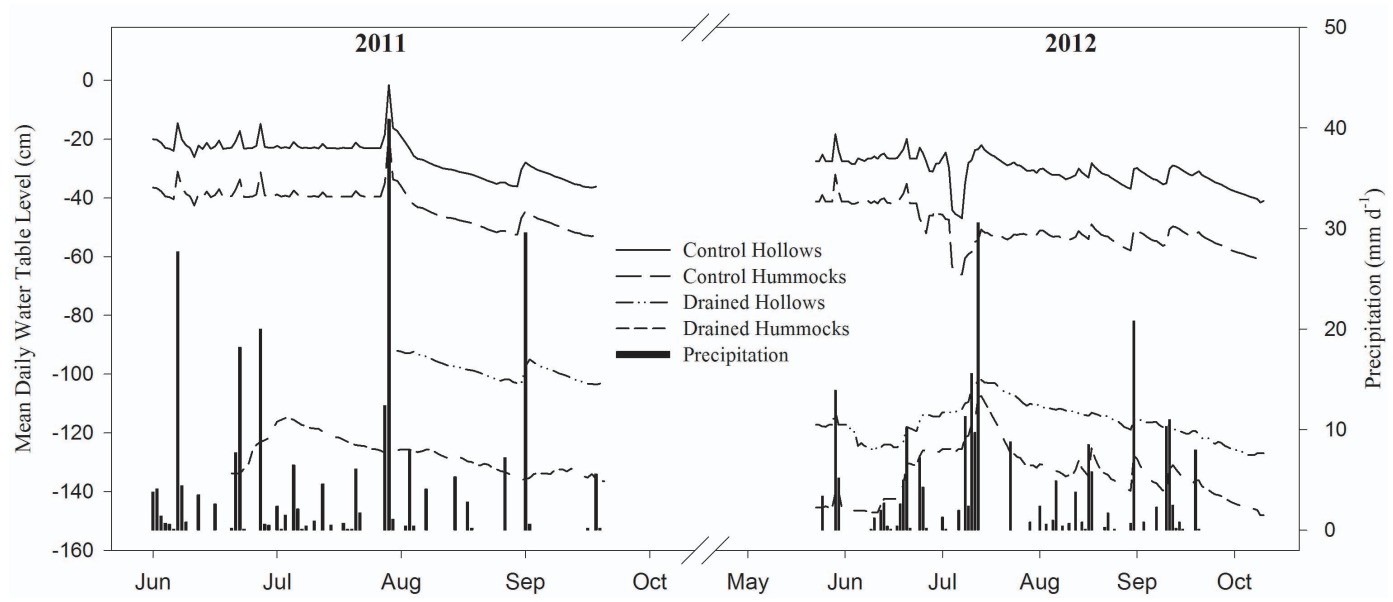

Fig. 2. Water table levels (lines) and daily precipitation (bars) during growing seasons of 2011 and 2012. The cumulative seasonal precipitation during 2012 was $30 \%$ less than that of 2011.

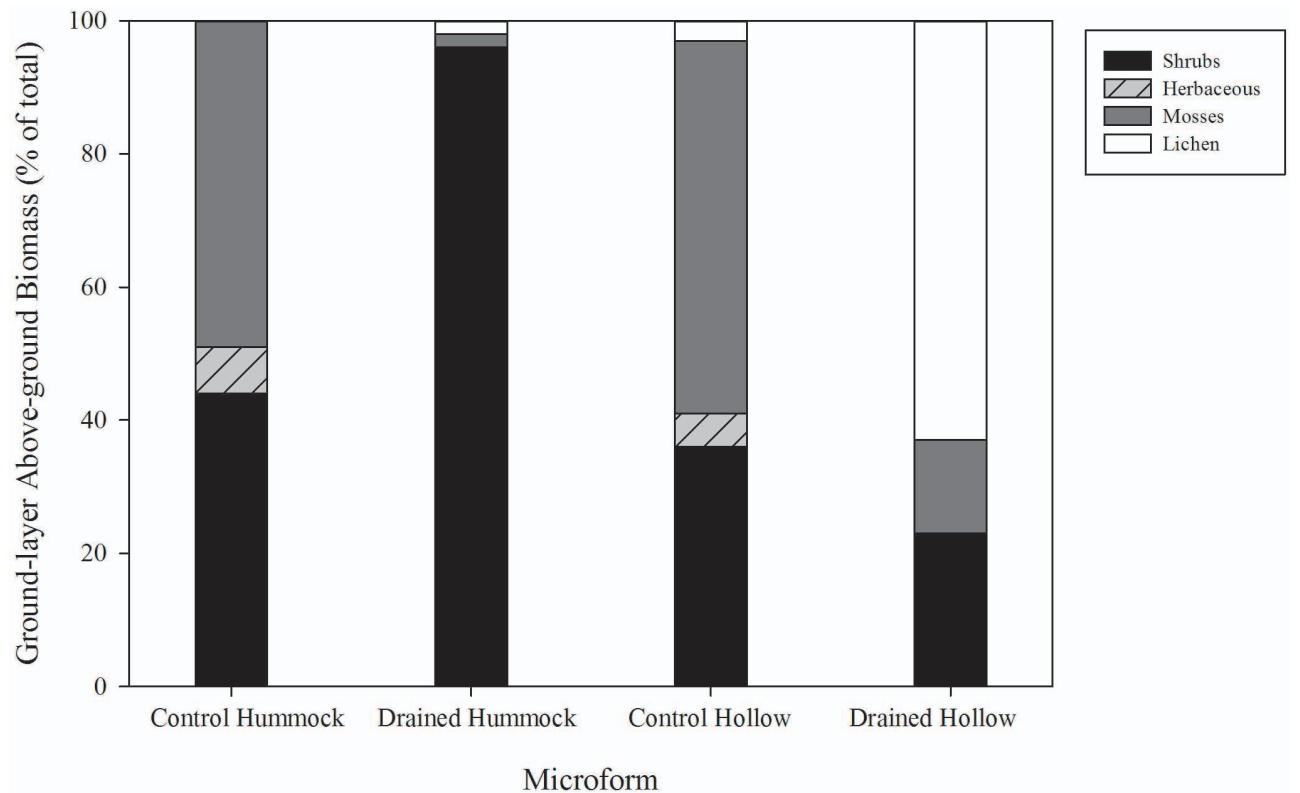

Fig. 3. Relationship between drainage/microform scenario and ground-layer aboveground biomass by category as a percentage of total.

larger sinks of $\mathrm{CO}_{2}$, while considerably reduced emissions at the drained hollows (Fig. 4).

\subsubsection{Modeled $\mathrm{CO}_{2}$ fluxes}

Based on empirical models (Eqs. 1 and 2), the ground layer at the control site was a small growing season sink of $\mathrm{CO}_{2}$ taking up an estimated $6.9 \mathrm{~g} \mathrm{CO}_{2} \mathrm{~m}^{-2}$ largely due to the significantly higher $\mathrm{GPP}_{\mathrm{ff}}$ at its hollows than that of its hummocks. In contrast, the ground layer at the drained site was a substantial source of $\mathrm{CO}_{2}$, losing an estimated $770 \mathrm{~g} \mathrm{CO}_{2} \mathrm{~m}^{-2}$ largely due to significantly higher $R_{\mathrm{ff}}$ at its hollows than that of its hummocks, during the 2011 growing season (Table 4). In 2012, a shift in the functions of hollows and hummocks at the control site was noticed, where hummocks became a moderate sink of $\mathrm{CO}_{2}$, and the hollows became a substantial source. However, the drained microforms and site remained consistently sources of $\mathrm{CO}_{2}$ (Table 4).

\section{$3.4 \mathrm{CO}_{2}-\mathrm{C}$ balance}

In the growing season of 2011, the forest floor (including $\left.R_{\mathrm{r}}\right)$ of control and drained sites were a small sink $\left(2 \mathrm{~g} \mathrm{CO}_{2}-\right.$ $\left.\mathrm{C} \mathrm{m}^{-2}\right)$ and substantial source $\left(210 \mathrm{~g} \mathrm{CO}_{2}-\mathrm{C} \mathrm{m}^{-2}\right)$, respectively. In the growing season of 2012, the control site became a moderate source $\left(20 \mathrm{~g} \mathrm{CO}_{2}-\mathrm{C} \mathrm{m}^{-2}\right)$ while the drained site remained a substantial source $\left(200 \mathrm{~g} \mathrm{CO}_{2}-\mathrm{C} \mathrm{m}^{-2}\right)$. To calculate the final $\mathrm{CO}_{2}-\mathrm{C}$ balance, we added estimated $\mathrm{NE}_{\mathrm{ff}}\left(-R_{\mathrm{r}}\right)$ 


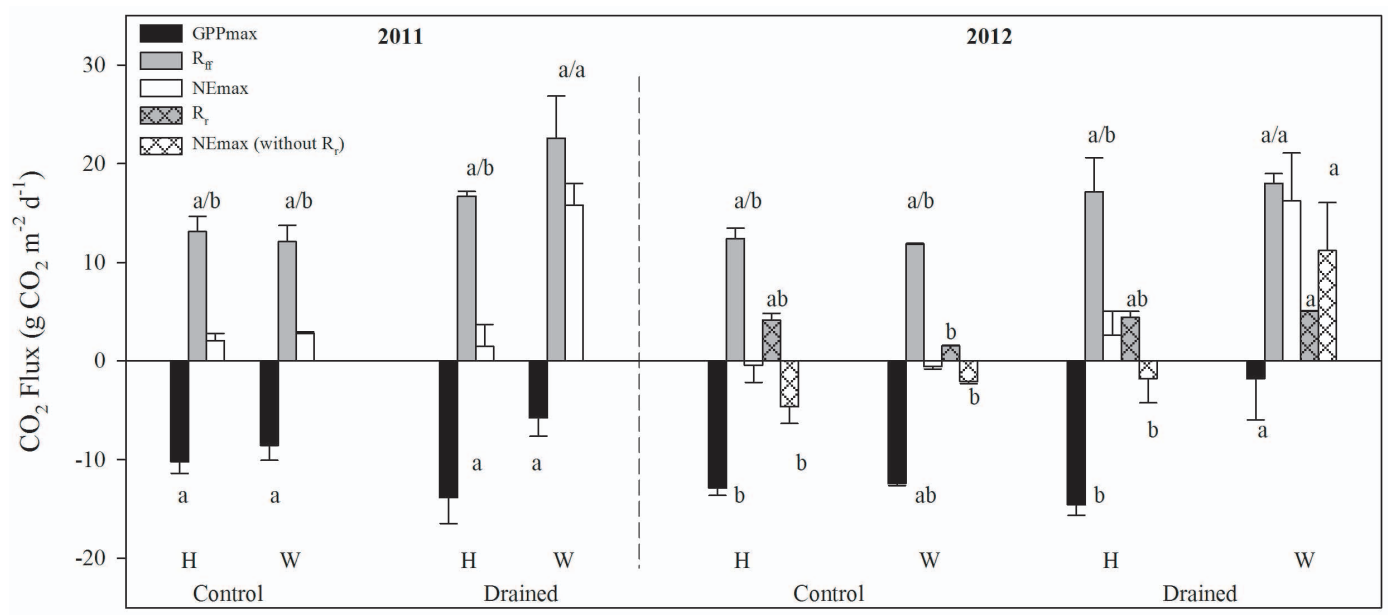

Fig. 4. GPP $\max , R_{\mathrm{ff}}$ and $\mathrm{NE}_{\max }$ at control and drained sites in 2011. The $R_{\mathrm{r}}$ measurements were added in 2012. NE $\max$ (without aboveand belowground parts of trees) was calculated by subtracting $R_{\mathrm{r}}$ from $\mathrm{NE}_{\mathrm{max}}$ and represents net exchange of $\mathrm{CO}_{2}$ of the ground-layer vegetation and peat. $\mathrm{H}$ and $\mathrm{W}$ represent hummocks and hollows, respectively. Error bars indicate \pm standard deviation. Results are from twoway (drainage and microform) ANOVA performed separately for growing season of each year. Differences were evaluated between study plots grouped according to microform and drainage and are indicted by letters at each bar. Sites are significantly different at $\mathrm{p}<0.05$ if they have no letters in common (letters should be compared only within one $\mathrm{CO}_{2}$ component in one year).

to estimated tree incremental growth $\left(\mathrm{IC}_{\text {tree_ag }}+\mathrm{IC}_{\text {tree_bg }}\right)$ and tree litter production $\left(L_{\text {tree }}\right)$ during the study years, and estimated that the control site was a larger sink of $-92 \mathrm{~g}$ $\mathrm{C} \mathrm{m}^{-2}$ in 2011 than that of $-70 \mathrm{~g} \mathrm{C} \mathrm{m}^{-2}$ in 2012. However, the drained site remained a source through both study seasons, losing $27 \mathrm{~g} \mathrm{C} \mathrm{m}^{-2}$ in 2011 and $23 \mathrm{~g} \mathrm{Cm}^{-2}$ in 2012 growing season. Importantly, majority of the discussion in this study focuses on the differences in the measured components as opposed to the $\mathrm{CO}_{2}-\mathrm{C}$ balance itself.

\section{Discussion}

The control site of this sub-humid, continental treed bog was a growing season sink of $\mathrm{CO}_{2}-\mathrm{C}$ of 92 and $70 \mathrm{~g} \mathrm{C} \mathrm{m}^{-2}$ in years slightly wetter and drier than average, respectively. Depending on time since fire, Wieder et al. (2009) report that treed bogs in the same region represent an annual $\mathrm{CO}_{2}$ sink of 120 to $220 \mathrm{~g} \mathrm{C} \mathrm{m}^{-2}$ and thus our value is slightly below this range. Within the same region of northern Alberta as the present study, Adkinson et al. (2011) report net growing season $\mathrm{CO}_{2}$ exchange across three study years of -110.1 and -153.5 to $-34.5 \mathrm{~g} \mathrm{C} \mathrm{m}^{-2}$ at poor fen and rich fen sites, respectively.

Previous research has shown that warm and dry summer conditions can reduce net $\mathrm{CO}_{2}$ uptake in peatlands by enhancing respiration greater than productivity (Alm et al., 1999; Arneth et al., 2002; Bubier et al., 2003; Aurela et al., 2007). Similarly, in our experiment drier weather in 2012 reduced net uptake of $\mathrm{CO}_{2}$ and reduced the growing season $\mathrm{C}$ sink at the control site. The shift was due to the substantially increased $R_{\mathrm{ff}}$ at the hollows greater than that of combined increase in $\mathrm{GPP}_{\mathrm{ff}}$ at the microforms (Table 4). The enhanced $R_{\mathrm{ff}}$ at hollows might be due to stressed vegetation growth observed at the drier hollows (Fig. 3). In contrast there was little change in $\mathrm{GPP}_{\mathrm{ff}}$ or $R_{\mathrm{ff}}$ at the drained site in 2012 and thus no real change in net $\mathrm{CO}_{2}$ emission.

Ten years of water table drawdown, converted our bog site forest floor from a small sink of $2 \mathrm{~g} \mathrm{~m}^{-2}$ in 2011 or a smaller source of $20 \mathrm{~g} \mathrm{~m}^{-2}$ in 2012 to a large source of $\mathrm{CO}_{2}$ of $\sim 200 \mathrm{~g} \mathrm{~m}^{-2}$ in both years. This value of net source of $\mathrm{CO}_{2}$ compares well with those of other drained peatlands as reported by Waddington et al. (2002), von Arnold et al. (2005) and Simola et al. (2012). Similar to our findings on response of warmer and drier weather, Aurela et al. (2007) and Lafleur and Humphreys (2008) also found increased GPP $_{\mathrm{ff}}$ with warmer growing season temperature but reduced $\mathrm{GPP}_{\mathrm{ff}}$ and enhanced $R_{\mathrm{ff}}$ at extreme temperature in a sub-arctic fen. Our findings together with others (e.g. Griffis et al., 2000; Bubier et al., 2003; Aurela et al., 2007; Wieder et al., 2009) demonstrate the important interaction between temperature and water availability for $\mathrm{GPP}_{\mathrm{ff}}$ and $R_{\mathrm{ff}}$ response, as either factor alone could not determine the overall growth response of peatland vegetation under changing climatic conditions. Persistently deep water table at the drained site likely limited any response to the short term drying in 2012 as this did little to further lower the water table.

Ten years of drainage in a dry continental boreal bog had a significant impact on the plant community, plant biomass and carbon fluxes, and the responses of the peatland to drainage varied between microforms and over time. Drainage replaced mosses with shrubs at hummocks and lichens at hollows such that the ground-layer aboveground biomass increased 
significantly (Fig. 3). The aboveground biomass appears to be within a range of previous reports for similar types of peatlands. Published data for aboveground tree biomass across 20 bogs and ground-layer shrubs biomass across 16 bogs varied quite broadly with means of $2177 \mathrm{~g} \mathrm{~m}^{-2}\left( \pm 2259 \mathrm{~g} \mathrm{~m}^{-2}\right)$ and $478 \mathrm{~g} \mathrm{~m}^{-2}\left( \pm 224 \mathrm{~g} \mathrm{~m}^{-2}\right)$, respectively (Moore et al., 2002). Our data for average total of the ground-layer and aboveground tree biomass $\left(3490 \pm 263 \mathrm{~g} \mathrm{~m}^{-2}\right)$ fall within the range of the published values. The drainage-induced increase in ground-layer biomass including above- and belowground biomass observed was also reported by Moore et al. (2002). We could measure belowground biomass to only $20 \mathrm{~cm}$ depth due to frozen lower layers of soil at the time of sampling and therefore it is likely that we may have underestimated the root biomass particularly at the drained site with large oxic zone. However, this still likely captured the majority of belowground biomass as Lieffers and Rothwell (1987) found only $6 \%$ of root biomass occurred below $20 \mathrm{~cm}$ deep in a drained bog.

Although aboveground tree biomass was slightly higher at control site due to denser but smaller diameter trees, we found higher total biomass at the drained site due to its significantly higher ground-layer biomass than that at the control site. In both of the study years, the tree productivity was significantly higher at the drained site than that at control. The higher belowground biomass supported with higher $R_{\mathrm{r}}$ at the drained site, is a strong indication that lowered water table enhanced tree growth as concluded by (Hanson et al., 2000), Hermle et al. (2010) and Lieffers and Rothwell (1987). Although we determined the contribution of $R_{\mathrm{r}}$ to $R_{\mathrm{ff}}$ in our treed peatland study, our main aim was to quantify and include $R_{\mathrm{ff}}$ in seasonal model construction. The drainage induced significantly higher coverage of vascular plants and ground-layer aboveground biomass offsets some of the loss of $\mathrm{CO}_{2}$ due to deeper oxic zone and higher decomposition rates as the water table drops (Ise et al., 2008). However, our carbon balance estimates suggest that drainage has led to a shift from $\mathrm{CO}_{2}$ sink to a $\mathrm{CO}_{2}$ source as the drainage-induced increase in $R_{\mathrm{ff}}$ (supported by $R_{\mathrm{r}}$ ) was substantially higher than that of increase in GPP in both study seasons of 2011 and 2012. Similarly, Chivers et al. (2009) conducted a water table drawdown response experiment in an Alaskan moderately rich, treeless fen and found after two years of drainage, similar to our finding, that the drainage shifted the peatland from a sink of $\mathrm{CO}_{2}$ to a source, although this change was much smaller than that of the change observed in our study of effects of drainage after $10 \mathrm{yr}$.

Peatland microforms have been shown to have different rates of $\mathrm{CO}_{2}$ exchange and respond differently to changes in environmental conditions. For example, Waddington and Roulet (2000) found significantly higher uptake of $\mathrm{CO}_{2}$ at a wetter microform (lawn) than that at the drier one (ridge) in over two growing seasons. Strack et al. (2006) studied $\mathrm{CO}_{2}$ exchange following water table drawdown along a microtopographic gradient in a cool temperate poor fen and com- pared results to a natural microtopographic gradient over two growing seasons. They also reported higher uptake of $\mathrm{CO}_{2}$ at the wetter microform (hollow). They found that drained hummocks had lower GPP max $_{\text {ax }}$ than drained hollows in contrast to control microforms and suggested that lower water tables would result in flattening of the peatland microtopography (i.e. hummocks shrink while hollows accumulate peat). In contrast, in the present study in a dry continental boreal treed bog, we found that after a decade of drainage the GPP max $_{\text {ax }}$ was in fact the highest at drained hummocks in both growing seasons. The increase in $\mathrm{GPP}_{\max }$ at drained hummocks was probably due to enhanced growth and greater coverage of shrubs. Conversely, replacement of Sphagnum by lichens at drained hollows (over 30 times higher biomass than at control hollows) probably led to the observed reduction in $\mathrm{GPP}_{\max }$ (Table 4). Moreover, the drained hollows were the largest source of $\mathrm{CO}_{2}$ in both years. Therefore we expect an increase in relative equilibrium peat depth at the hummocks and decrease in equilibrium peat depth at the hollows as an effect of drainage over the long run. These findings are not consistent with Strack et al. (2006) and are likely due to contrasting climate conditions of the two studies. For example, the earlier study was conducted in an open poor fen where average growing season precipitation recorded during the two study years were 433 and $358 \mathrm{~mm}$ in contrast to 402 and $281 \mathrm{~mm}$ recorded at our treed continental bog. Also the water table in the earlier study was much shallower and linked to regional hydrology whereas the much deeper water table in this study was controlled by the precipitation and the local elevation. On the other hand, these results together are consistent with a general "humpbacked" relationship between peat accumulation and water table depth (e.g., Belyea and Clymo, 2001; Belyea, 2009). Given the initially dry conditions at this continental bog, further drying is expected to shift both hummocks and hollows to lower rates of peat accumulation whereas a flattening of the curve at deep water tables (reduced effect of water table change on peat accumulation at drier sites) would reduce this effect at already dry sites (e.g. hummocks).

To sum up, the drained continental bog compared with a natural one simulated the potential climate-induced lowered water table and revealed spatial and temporal heterogeneity in $\mathrm{CO}_{2}$ fluxes and plant biomass in the treed peatland complex. Drainage affected vegetation coverage, plant biomass and $\mathrm{CO}_{2}$ fluxes differently at the microforms after a decade. Significant replacement of mosses with shrubs at hummocks and lichens at hollows increased ground-layer aboveground biomass significantly at the hummocks and generally at the hollows. This drainage-induced change in vegetation coverage and biomass shifted the bog from a sink of $\mathrm{CO}_{2}$ to a source despite an increase in tree productivity. Net emission of $\mathrm{CO}_{2}$ can decelerate the rate of vertical growth of microforms, whereas net uptake of $\mathrm{CO}_{2}$ can accelerate the rate of vertical growth (Belyea, 2009). In this study we noticed significant increase in net $\mathrm{CO}_{2}$ uptake at hummocks and net 
release at hollows as a result of $10 \mathrm{yr}$ of drainage (Table 4) in contrast to previous studies in wetter climates. This illustrates the importance of initial climatic conditions for predicting peatland response (e.g. Hilbert et al., 2000). Continued low water tables could lead to further shifts in vegetation in the future and thus a different $\mathrm{CO}_{2}-\mathrm{C}$ balance than determined following $10 \mathrm{yr}$ of water table drawdown.

\section{Conclusions}

Ten years of drainage in an ombrotrophic treed bog induced ecological succession: mosses were replaced by shrubs at hummocks and lichens at hollows. The overall greater coverage of vascular plants and higher total biomass at the drained site increased the uptake of $\mathrm{CO}_{2}$ but the loss via respiration was even higher due to peat oxidation and increased contribution of tree root respiration. The research strongly suggests that the deepening of the unsaturated zone affected $\mathrm{C}$ sequestration rates differently at hummocks and hollows, potentially resulting in steepened microtopographic gradient over time. Overall, drainage promoted $\mathrm{CO}_{2}$ emissions but offset a portion of these losses by increasing total biomass in a dry continental boreal treed bog.

Acknowledgements. This research was funded by a New Faculty Award from Alberta Innovates Technology Futures to MS Sungro Horticulture provided site access. We thank Jordanna Branham, Magnus Keith, Sharif Mahmood for assistance with fieldwork, Tak Fung for statistical support and Rick Smith for technical support for the meteorological station. Comments by two anonymous reviewers greatly improved the manuscript.

Edited by: T. Laurila

\section{References}

Adkinson, A. C., Syed, K. H., and Flanagan, L. B.: Contrasting responses of growing season ecosystem $\mathrm{CO}_{2}$ exchange to variation in temperature and water table depth in two peatlands in northern Alberta, Canada, J. Geophys. Res.-Biogeosci., 116, G01004, doi:10.1029/2010jg001512, 2011.

Alm, J., Schulman, L., Walden, J., Nykänen, H., Martikainen, P. J., and Silvola, J.: Carbon balance of a boreal bog during a year with an exceptionally dry summer, Ecology, 80, 161-174, 1999.

Arneth, A., Kurbatova, J., Kolle, O., Shibistova, O. B., Lloyd, J., Vygodskaya, N. N., and Schulze, E. D.: Comparative ecosystematmosphere exchange of energy and mass in a European Russian and a central Siberian bog II. Interseasonal and interannual variability of CO2 fluxes, Tellus B, 54, 514-530, 2002.

Aurela, M., Riutta, T., Laurila, T., Tuovinen, J. P., Vesala, T., Tuittila, E. S., Rinne, J., Haapanala, S., and Laine, J.: CO2 exchange of a sedge fen in southern Finland-the impact of a drought period, Tellus B, 59, 826-837, 2007.

Belyea, L. R.: Nonlinear dynamics of peatlands and potential feedbacks on the climate system, in: Carbon Cycling in Northern
Peatlands, Geophys. Monogr. Ser., AGU, Washington, DC, 518, 2009.

Belyea, L. R. and Clymo, R.: Feedback control of the rate of peat formation, Proceedings of the Royal Society of London. Series B: Biological Sciences, 268, 1315-1321, 2001.

Blodau, C. and Siems, M.: Drainage-induced forest growth alters belowground carbon biogeochemistry in the Mer Bleue bog, Canada, Biogeochemistry, 107, 107-123, 2012.

Boone, R. D., Nadelhoffer, K. J., Canary, J. D., and Kaye, J. P.: Roots exert a strong influence on the temperature sensitivity of soil respiration, Nature, 396, 570-572, 1998.

Bowden, R. D., Nadelhoffer, K. J., Boone, R. D., Melillo, J. M., and Garrison, J. B.: Contributions of above ground litter, below ground litter, and root respiration to total soil respriation in a temperate mixed hardwood forest, Can. J. Forest Res, 23, 1402 1407, 1993.

Brant, J. B., Myrold, D. D., and Sulzman, E. W.: Root controls on soil microbial community structure in forest soils, Oecologia, 148, 650-659, 2006.

Bubier, J. L., Bhatia, G., Moore, T. R., Roulet, N. T., and Lafleur, P. M.: Spatial and temporal variability in growing-season net ecosystem carbon dioxide exchange at a large peatland in Ontario, Canada, Ecosystmes, 6, 353-367, 2003.

Cai, T., Flanagan, L. B., and Syed, K. H.: Warmer and drier conditions stimulate respiration more than photosynthesis in a boreal peatland ecosystem: Analysis of automatic chambers and eddy covariance measurements, Plant Cell and Environment, 33, 394 407, 2010.

Camill, P.: Patterns of boreal permafrost peatland vegetation across environmental gradients sensitive to climate warming, Can. J. Botany, 77, 721-733, 1999.

Carlson, M., Chen, J., Elgie, S., Henschel, C., Montenegro, A., Roulet, N. T., Scott, N., Tarnocai, C., and Wells, J.: Maintaining the role of Canada's forests and peatlands in climate regulation, The Forestry Chronicle, 86, 434-443, 2010.

Chapman, S. J., and Thurlow, M.: Peat respiration at low temperatures, Soil Biol. Biochem., 30, 1013-1021, 1998.

Charman, D. and Chichester: Peatlands and Environmental Change, John Wiley and Sons Ltd, Chichester, 2002.

Chivers, M., Turetsky, M., Waddington, J., Harden, J., and McGuire, A.: Effects of experimental water table and temperature manipulations on ecosystem carbon dioxide fluxes in an Alaskan rich fen, Ecosystems, 12, 1329-1342, 2009.

Clymo, R. S.: The growth of Sphagnum: methods of measurement, J. Ecol., 58, 13-49, 1970.

Davidson, E. A. and Janssens, I. A.: Temperature sensitivity of soil carbon decomposition and feedbacks to climate change, Nature, 440, 165-173, 2006.

Díaz Pinés, E., Schindlbacher, A., Pfeffer, M., Jandl, R., Zechmeister-Boltenstern, S., and Agustín, R.: Root trenching: a useful tool to estimate autotrophic soil respiration? A case study in an Austrian mountain forest, Europ. J. Forest Res., 125, 101109, 2010.

Edwards, N. T. and Norby, R. J.: Below-ground respiratory responses of sugar maple and red maple samplings to atmospheric $\mathrm{CO}_{2}$ enrichment and elevated air temperature, Plant Soil, 206, 85-97, 1999. 
Gorham, E.: Northern Peatlands: Role in the carbon cycle and probable responses to climatic warming, Ecol. Appl., 1, 182-195, 1991.

Griffis, T. J., Rouse, W. R., and Waddington, J. M.: Interannual variability of net ecosystem $\mathrm{CO}_{2}$ exchange at a subarctic fen, Global Biogeochemical Cycles, 14, 1109-1121, 2000.

Grigal, D. F. and Kernik, L. K.: Generality of black spruce biomass estimation equations, Can. J. Forest Res., 14, 468-470, 1984.

Gruber, N., Friedlingstein, P., B, F. C., Valentini, R., Heimann, M., Richey, J. E. P., Romero-Lankao, Schulze, E.-D., and Chen, C.T. A.: The vulnerability of the carbon cycle in the 21 st Century: An assessment of carbon-climate-human interactions, The Global Carbon Cycle: Integrating Humans, Climate, and the Natural World, Washington, DC, 2004.

Hanson, P. J., Edwards, N. T., Garten, C. T., and Andrews, J. A.: Separating root and soil microbial contributions to soil respiration: A review of methods and observations, Biogeochemistry, 48, 115-146, 2000.

Heikurainen, L. and Pakarinen, P.: Peatland classification. In Peatlands and their utilization in Finland, Finnish National Committee of the International Peat Society, Helsinki, 1982.

Hengeveld, H. G.: Projections for Canada's climate future, Climate change digest, 500, 1-27, 2000.

Hermle, S., Lavigne, M. B., Bernier, P. Y., Bergeron, O., and Pare, D.: Component respiration, ecosystem respiration and net primary production of a mature black spruce forest in northern Quebec, Tree Physiology, 30, 527-540, 2010.

Hilbert, D. W., Roulet, N., and Moore, T.: Modelling and analysis of peatlands as dynamical systems, Journal of Ecology, 88, 230242, 2000.

IPCC: Impacts, Adaptation and Vulnerability: Contribution of working group II to the fourth assessment report of the intergovernmental panel on climate change, edited by: Parry, M. L., Canziani, O. F., Palutikof, J. P., van der Linden, P. J., and Hanson, C. E., Cambridge University Press, Cambridge, United Kingdom, 976 pp., 2007.

Ise, T., Dunn, A. L., Wofsy, S. C., and Moorcroft, P. R.: High sensitivity of peat decomposition to climate change through watertable feedback, Nat. Geosci., 1, 763-766, 2008.

Janssens, I. A., Lankreijer, H., and Matteucci, G.: Productivity overshadows temperature in determining soil and ecosystem respiration across European forests, Glob. Change Biol., 269-278, 2001.

Joosten, H. and Clarke, D.: Wise use of mires and peatlands, International mire conservation group, 2002.

Koskinen, M., Minkkinen, K., Ojanen, P., Kämäräinen, M., Laurila, T., and Lohila, A.: Measurements of $\mathrm{CO}_{2}$ exchange with an automated chamber system throughout the year: challenges in measuring nighttime respiration on porous peat soil, Biogeosciences Discuss., 10, 14195-14238, 2013, http://www.biogeosciences-discuss.net/10/14195/2013/.

Kutzbach, L., Schneider, J., Sachs, T., Giebels, M., Nykänen, H., Shurpali, N. J., Martikainen, P. J., Alm, J., and Wilmking, M.: $\mathrm{CO}_{2}$ flux determination by closed-chamber methods can be seriously biased by inappropriate application of linear regression, Biogeosciences, 4, 1005-1025, doi:10.5194/bg4-1005-2007, 2007.

Kuzyakov, Y.: Sources of $\mathrm{CO}_{2}$ efflux from soil and review of partitioning methods, Soil Biol. Biochem., 425-448, 2006.
Lafleur, P. M. and Humphreys, E. R.: Spring warming and carbon dioxide exchange over low Arctic tundra in central Canada, Glob. Change Biol., 14, 740-756, 2008.

Lai, D. Y. F., Roulet, N. T., Humphreys, E. R., Moore, T. R., and Dalva, M.: The effect of atmospheric turbulence and chamber deployment period on autochamber $\mathrm{CO}_{2}$ and $\mathrm{CH}_{4}$ flux measurements in an ombrotrophic peatland, Biogeosciences, 9, 33053322, doi:10.5194/bg-9-3305-2012, 2012.

Li, Z., Kurz, W. A., Apps, M. J., and Beukema, S. J.: Belowground biomass dynamics in the Carbon Budget Model of the Canadian Forest Sector: recent improvements and implications for the estimation of NPP and NEP, Can. J. Forest Res., 33, 126-136, 2003.

Lieffers, V. and Rothwell, R.: Rooting of peatland black spruce and tamarack in relation to depth of water table, Can. J. Botany, 65, 817-821, 1987.

Limpens, J., Berendse, F., Blodau, C., Canadell, J. G., Freeman, C., Holden, J., Roulet, N., Rydin, H., and Schaepman-Strub, G.: Peatlands and the carbon cycle: from local processes to global implications - a synthesis, Biogeosciences, 5, 1475-1491, doi:10.5194/bg-5-1475-2008, 2008.

Lohila, A., Minkkinen, K., Aurela, M., Tuovinen, J.-P., Penttilä, T., Ojanen, P., and Laurila, T.: Greenhouse gas flux measurements in a forestry-drained peatland indicate a large carbon sink, Biogeosciences, 8, 3203-3218, doi:10.5194/bg-8-3203-2011, 2011.

Loisel, J., Gallego-Sala, A. V., and Yu, Z.: Global-scale pattern of peatland Sphagnum growth driven by photosynthetically active radiation and growing season length, Biogeosciences, 9, 27372746, doi:10.5194/bg-9-2737-2012, 2012.

Macdonald, S. E. and Lieffers, V. J.: Photosynthesis, water relations, and foliar nitrogen of Picea mariana and Larix laricina from drained and undrained peatlands, Can. J. Forest Res., 20, 995-1000, 1990.

Moore, P. D.: The future of cool temperate bogs, Environmental Conservation, 29, 3-20, 2002.

Moore, T. R., and Dalva, M.: The influence of temperature and water table position on carbon dioxide and methane emissions from laboratory columns of peatland soils, J. Soil Sci., 44, 651-664, 1993.

Moore, T. R., Bubier, J. L., Frolking, S. E., Lafleur, P. M., and Roulet, N. T.: Plant biomass and production and $\mathrm{CO}_{2}$ exchange in an ombrotrophic bog, J. Ecol., 90, 25-36, 2002.

Moore, T. R., Lafleur, P. M., Poon, D. M. I., Heumann, B. W., Seaquist, J. W., and Roulet, N. T.: Spring photosynthesis in a cool temperate bog, Global Change Biol., 12, 2323-2335, 2006.

Mullin, T., Morgenstern, E., Park, Y., and Fowler, D.: Genetic parameters from a clonally replicated test of black spruce (Picea mariana), Can. J. Forest Res., 22, 24-36, 1992.

Ow, L. F., Griffin, K. L., Whitehead, D., Walcroft, A. S., and Turnbull, M. H.: Thermal acclimation of leaf respiration but not photosynthesis in Populus deltoides $\times$ nigra, New Phytologist, 178, 123-134, 2008.

Parmentier, F., Van der Molen, M., de Jeu, R., Hendriks, D., and Dolman, A.: $\mathrm{CO}_{2}$ fluxes and evaporation on a peatland in the Netherlands appear not affected by water table fluctuations, Agr. Forest Meteorol., 149, 1201-1208, 2009.

Price, J. S.: The Hydrology of Peatlands of Eastern Canada, in: Ecologie des tourbieres du Quebex and Labrador, edited by: Payette, S. a. R., L, 141-158, 2010. 
Rey, A., Pegoraro, E., Tedeschi, V., De-Parri, I., Jarvis, P. G., and Valentini, R.: Annual variation in soil respiration and its components in a coppice oak forest in Central Italy, Glob. Change Biol., 851-866, 2002.

Riley, J. L.: The Vascular Flora of the Hudson Bay Lowland and Its Postglacial Origins, NRC Research Press, 2003.

Riutta, T., Laine, J., Aurela, M., Rinne, J., Vesala, T., Laurila, T., Haapanala, S., Pihlatie, M., and Tuittila, E. S.: Spatial variation in plant community functions regulates carbon gas dynamics in a boreal fen ecosystem, Tellus B, 59, 838-852, 2007.

Robroek, B. J. M., Schouten, M. G. C., Limpens, J., Berendse, F., and Poorter, H.: Interactive effects of water table and precipitation on net $\mathrm{CO} 2$ assimilation of three co-occurring Sphagnum mosses differing in distribution above the water table, Glob. Change Biol., 15, 680-691, 2009.

Roulet, N.: Peatlands, carbon storage, greenhouse gases, and the Kyoto Protocol: Prospects and significance for Canada, Wetlands, 20, 605-615, 2000

Roulet, N. T., Moore, T. I. M., Bubier, J., and Lafleur, P.: Northern fens: methane flux and climatic change, Tellus B, 44, 100-105, 1992.

Roulet, N. T., Lafleur, P. M., Richard, P. J. H., Moore, T. R., HumphreySk, E. R., and Bubier, J.: Contemporary carbon balance and late Holocene carbon accumulation in a northern peatland, Glob. Change Biol., 13, 397-411, 2007.

Ryan, M. G.: Foliar maintenance respiration of subalpine and boreal trees and shrubs in relation to nitrogen content, Plant, Cell and Environ., 18, 765-772, 1995.

Simola, H., Pitkänen, A., and Turunen, J.: Carbon loss in drained forestry peatlands in Finland, estimated by re-sampling peatlands surveyed in the 1980s, Europ. J. Soil Sci., 63, 798-807, 2012.

Strack, M., Waddington, J., Rochefort, L., and Tuittila, E. S.: Response of vegetation and net ecosystem carbon dioxide exchange at different peatland microforms following water table drawdown, J. Geophys. Res. (2005-2012), 111, G02006, 2006.

Syed, K. H., Flanagan, L. B., Carlson, P. J., Glenn, A. J., and Van Gaalen, K. E.: Environmental control of net ecosystem $\mathrm{CO}_{2}$ exchange in a treed, moderately rich fen in northern Alberta, Agr. Forest Meteorol., 140, 97-114, 2006.

Szumigalski, A. R. and Bayley, S. E.: Net above-ground primary production along a bog-rich fen gradient in central Alberta, Canada, Wetlands, 16, 467-476, 1996.

Tarnocai, C.: The effect of climate change on carbon in Canadian peatlands, Glob. Planet. Change, 53, 222-232, 2006.

Tarnocai, C., Canadell, J. G., Schuur, E. A. G., Kuhry, P., Mazhitova, G., and Zimov, S.: Soil organic carbon pools in the northern circumpolar permafrost region, Glob. Biogeochem. Cy., 23, GB003327, doi:10.1029/2008gb003327, 2009.

Thormann, M. N. and Bayley, S. E.: Aboveground net primary production along a bog-fen-marsh gradient in southern boreal Alberta, Canada, Ecoscience, 4, 374-384, 1997.

Tokida, T., Mizoguchi, M., Miyazaki, T., Kagemoto, A., Nagata, O., and Hatano, R.: Episodic release of methane bubbles from peatland during spring thaw, Chemosphere, 70, 165-171, doi:10.1016/j.chemosphere.2007.06.042, 2007.
Tuittila, E. S., Vasander, H., and Laine, J.: Sensitivity of C Sequestration in Reintroduced Sphagnum to Water-Level Variation in a Cutaway Peatland, Rest. Ecol., 12, 483-493, 2004.

Turetsky, M., Wieder, K., Halsey, L., and Vitt, D.: Current disturbance and the diminishing peatland carbon sink, Geophys. Res. Lett., 10, 131 pp., doi:10.1029/2001GL014000, 2002.

Turunen, J., Tomppo, E., Tolonen, K., and Reinikainen, A.: Estimating carbon accumulation rates of undrained mires in Finlandapplication to boreal and subarctic regions, The Holocene, 12, 69-80, 2002.

Updegraff, K., Bridgham, S. D., Pastor, J., Weishampel, P., and Harth, $\mathrm{C} .:$ Response of $\mathrm{CO}_{2}$ and $\mathrm{CH}_{4}$ emissions from peatlands to warming and water table manipulation, Ecol. Appl., 11, 311326, 2001.

Valentini, R., Matteucci, G., and Dolman, A. J.: Respiration as the main determinant of carbon balance in European forests, Nature, 861-865, 2000.

Varem-Sanders, T. M. L. and Campbell, I. D.: DendroScan: a treering width and density measurement system. Canadian Forest Service, Northern Forestry Centre, Edmonton, Alta. Spec. Rep., 10, 131 pp., 1996.

Vitt, D. H., Halsey, L. A., Thormann, M. N., and Martin, T.: Peatland Inventory of Alberta. Phase 1: Overview of Peatland Resources in the Natural Regions and Subregions of the Province. Sustainable Forest Management Network, University of Alberta, Edmonton, Alberta, 1998.

Vitt, D. H., Wieder, R. K., Scott, K. D., and Faller, S.: Decomposition and peat accumulation in rich fens of boreal Alberta, Canada, Ecosystems, 12, 360-373, 2009.

von Arnold, K., Hånell, B., Stendahl, J., and Klemedtsson, L.: Greenhouse gas fluxes from drained organic forestland in Sweden, Scand. J. Forest Res., 20, 400-411, 2005.

Waddington, J., Warner, K., and Kennedy, G.: Cutover peatlands: a persistent source of atmospheric $\mathrm{CO}_{2}$, Global Biogeochem. Cy. 16, 1002, doi:10.1029/2001GB001398, 2002.

Waddington, J. M. and Price, J. S.: Effect of peatland drainage, harvesting, and restoration on atmospheric water and carbon exchange Physical Geography [Phys. Geogr.], 21, 433-451, 2000. Waddington, M. J. and Roulet, N. T.: Carbon balance of a boreal patterned peatland., Glob. Change Biol., 6, 87-97, 2000.

Wang, X., Zhu, B., Wang, Y., and Zheng, X.: Field measures of the contribution of root respiration to soil respiration in an alder and cypress mixed plantation by two methods: trenching method and root biomass regression method, Europ. J. Forest Res., 127, 285291, 2008.

Weltzin, J. F., Pastor, J., Harth, C., Bridgham, S. D., Updegraff, K., and Chapin, C. T.: Response of bog and fen plant communities to warming and water-table manipulations, Ecology, 81, 3464 3478, 2000.

Wieder, R. K., Scott, K. D., Kamminga, K., Vile, M. A., Vitt, D. H., Bone, T., Xu, B., Benscoter, B. W., and Bhatti, J. S.: Postfire carbon balance in boreal bogs of Alberta, Canada, Glob. Change Biol., 15, 63-81, 2009. 